\title{
MINAT INVESTASI SAHAM PADA MAHASISWA
}

\author{
Sri Andriani ${ }^{1}$, Andriaz Septianto Pohan ${ }^{1}$, \\ ${ }^{1}$ Program Studi Manajemen, Fakultas Ekonomi dan Bisnis Universitas Teknologi Sumbawa \\ *)e-mail: sri.amdriani@uts.ac.id
}

\begin{abstract}
ABSTRAK
Galeri investasi merupakan salah satu sarana yang disediakan oleh Bursa Efek Indonesia (BEI) untuk mengenalkan alternatif investasi di pasar modal (saham) pada masyarakat khsusnya mahasiswa. BEI dan OJK berusaha untuk memberikan edukasi sedini mungkin tentang investasi sehingga akan mengurangi konsumsi yang berlebihan ditengah masyarakat. Tujuan dari penelitian ini adalah untuk mengidentifikasi pengaruh keberadaan galeri investasi terhadap minat mahasiswa Program Studi Manajemen untuk investasi saham. Jenis penelitian ini adalah deskriptif dengan responden mahasiswa Program Studi Manajemen Fakultas Ekonomi dan Bisnis UTS. Hasil dari penelitian ini diidentifikasi ada beberapa indikator yang menjadi faktor yang mempengaruhi minat investasi saham mahasiswa dengan galeri investasi sebagai media edukasi yaitu sarana dan prasarana, kualitas SDM, kualitas sosialisasi dan pelatihan, harga dan minimal investasi, dan minat.
\end{abstract}

Kata Kunci: pasar modal, investasi saham, galeri investasi, OJK, BEI

\section{Pendahuluan}

Investasi merupakan salah satu alternative mendapatkan keuntungan yang cukup efektif. Investasi dapat dilakukan dalam berbagai bentuk baik dalam bentuk rill maupun non riil. Investasi yang mengikuti perkembangan zaman salahsatunya investasi di pasar modal. Investasi pasar modal dapat dilakukan pada jenis instrumen investasi dengan risiko yang cukup tinggi, misalnya pada aset-aset finansial seperti saham, warrants, options, serta futures baik di pasar modal domestik maupun di pasar modal internasional. Alternatif investasi yang menjanjikan pendapatan tinggi dengan risiko yang tinggi adalah investasi dalam bentuk saham. (Auruma dan Sudana, 2013)

Preferensi investasi memiliki alasan yang berbeda-beda dalam menentukan pilahn investasi. Faktor yang menjadi hal utama untuk dijadikan pertimbangan adalah tingkat risk dan return. Kecendrungan yang terjadi adalah keinginan seseorang memperoleh return yang tinggi dengan risk yang rendah. Semakin tinggi risk maka akan semakin tinggi juga return yang akan diperoleh. (Jogiyanto dalam Tandio, 2016)

Indonesia masih menjadi daya tarik bagi investor untuk menanamkan modalnya di Indonesia bahkan mengalahkan negara Thailand dan Malaysia. Faktor yang mempengaruhi besarnya minat investasi, karena penyederhaan perizinan investasi di dalam negeri, termasuk birokrasi regulasi yang tumpang tindih. Data harian ekonomi terkemuka asal Inggris, The Economist, menyebutkan untuk tahun 2015 Indonesia bertengger di peringkat kedua setelah China sebagai tujuan investasi dunia. Data Badan Koordinasi Penanaman Modal (BKPM) menunjukkan, realisasi Penanaman Modal Asing (PMA) dan Penanaman Modal Dalam Negeri (PMDN) pada semester pertama 2015 naik dibanding periode yang sama di tahun sebelumnya. Jumlah tenaga kerja yang terserap pun cukup signifikan, sekitar 685 ribu orang.

Bursa Efek Indonesia (BEI) mencatatkan pertumbuhan jumlah investor aktif, didominasi oleh masyarakat dengan rentang usia 17 tahun--30 tahun. Direktur Pengembangan BEI Nicky Hogan mengatakan generasi muda memang menjadi salah satu target BEI. Oleh karena itu BEI akan semakin gencar dalam melakukan sosialisasi dan edukasi, khususnya kepada masyarakat generasi muda. BEI mencatat pertumbuhan jumlah investor baru yang aktif bertransaksi di Pasar Modal di 2016 untuk usia 21 sampai dengan 25 tahun tercatat sebesar 7.899 investor. Usia 26 hingga 30 tahun tercatat 5.819 investor baru, dan usia 17 sampai dengan 20 tahun sebanyak 5.398 investor baru. Sepanjang 2016 BEI telah berhasil mengajak 101.887 orang untuk mau bertransaksi dan menjadi investor di Pasar Modal Indonesia. Berikut ini disajikan penyebaran invostor saham secara domestik.

Gambar 1.1. Penyebaran Investor Domestik di Indonesia

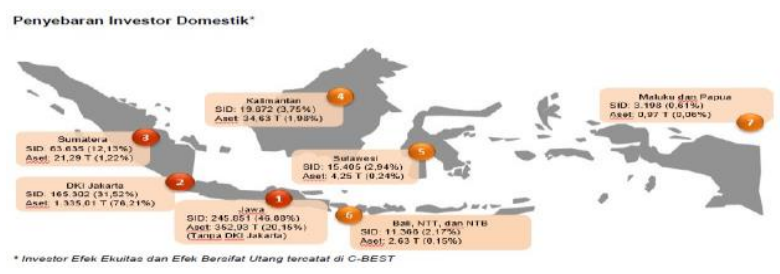

(Sumber : www.ojk.go.id)

Dalam situs pasar modal.inilah.com mengatakan bahwa pada tahun 2015 jumlah investor di NTB sebanyak 1.034 orang dan pada tahun 2016 terjadi peningkatan sebanyak 519 orang. Ribuan investor tersebar di Kota Mataram sebanyak 859 rekening, Kabupaten Lombok Barat 147 rekening, Lombok Tengah 67 rekening, Lombok Timur 108 rekening, Lombok Utara 3 rekening. Selain itu, di Kota Bima dan Kabupaten Bima sebanyak 127 rekening, Kabupaten Dompu 36 rekening, Sumbawa 171 rekening dan Sumbawa Barat sebanyak 35 rekening. Hal ini mengindikasikan bahwa terjadi pertumbuhan investor saham di NTB bisa tumbuh dengan signifikan sebagai akibat rasa aman, nyaman dan peningkatan pemahaman masyarakat atas produk pasar modal.

Untuk di Pulau Sumbawa, Kabupaten Sumbawa menduduki peringkat tertinggi dari jumlah investor saham. Hal ini tentunya memberikan gambaran secara ringkas bahwa 
potensi penambahan investor terutama investor muda masih cukup tinggi. Ditambah dengan adanya galeri investasi di Universitas Teknologi Sumbawa yang memfasilitasi semua kalangan baik siswa, mahasiswa, dosen maupun masyarakat umum. Keberadaan galeri investasi sangat berperan besar dalam memperkenalkan pasar modal di Kabupaten Sumbawa.

Penelitian ini akan fokus menganalisis peran galeri investasi yang merupakan perpanjangan peran dari OJK dan BEI dalam mensosialisasikan dan meningkatkan pengetahuan dan minat masyarakat terutama mahasiswa, dalam hal ini mahasiswa Program Studi Manajemen Fakultas Ekonomi dan Bisnis (FEB) Universitas Teknologi Sumbawa (UTS). Berdasarkan data dari pengelola Galeri Investasi FEB UTS, dari jumlah mahasiswa Program Studi Manajemen FEB UTS sebesar 205 mahasiswa, mahasiswa yang memiliki account investasi saham melalui Sinar Mas Sekuritas ada sekitar 30 mahasiswa. Data ini belum menggambarkan pengguna account yang aktif, hal ini dikarenakan keterbatasan pemahaman mahasiswa dalam melakukan trading saham. Untuk itu, perlu dilakukan kajian yang lebih mendalam tentang factor-faktor apa saja yang dapat meningkatkan minat investasi saham melalui Galeri Investasi FEB UTS di dalam mengakomodir dan menyamakan tujuan yang ingin dicapai sejak awal tercetusnya pendirian galeri tersebut.

\section{Metode Penelitian}

Jenis penelitian ini adalah deskriptif. Teknik pengumpulan data menggunakan dua metode yaitu penelitian lapangan dan penelitian kepustakaan. Lokasi penelitian di Universitas Teknologi Sumbawa (UTS). Objek penelitian adalah mahasiswa Program Studi Manajemen Fakultas Ekonomi dan Bisnis UTS. Sumber data berupa hasil penyebaran kuisioner dan wawancara terhadap responden yaitu mahasiswa program studi Manajemen FEB UTS yang terpilih menjadi sampel dan data sekunder berupa data pendukung maupun informasi yang didapat dari bagian akademik.

\section{Pembahasan}

\section{Profil Galeri Investasi}

Penyebarluasan informasi dan sosialisasi tentang Pasar Modal di Indonesia dinilai sangat berperan penting dalam memasyarakatkan fungsi dan peran Pasar Modal bagi perekonomian Indonesia. Program-program yang dilakukan secara terpadu dan terarah akan mengembangkan dan meningkatkan pengetahuan masyarakat tentang pentingnya melakukan investasi sejak dini. Pengetahuan itu tak terkecuali didapat di area Perguruan Tinggi. Sebagai pusat informasi di bidang pasar modal diharapkan dapat memberikan informasinya pada pengguna baik di lingkungan civitas akademika maupun bagi masyarakat umum.

Pendirian Galeri Investasi Bursa Efek Indonesia (BEI) dimaksudkan untuk mengenalkan Pasar Modal sejak dini pada dunia akademis. Pendirian Galeri Investasi BEI berkonsep 3 in 1 (kerjasama antara BEI, Perguruan Tinggi dan Perusahaan Sekuritas) sehingga diharapkan civitas akademika tidak hanya mengenal Pasar Modal dari sisi teori saja akan tetapi dapat langsung melakukan prakteknya. Sasaran Galeri Investasi BEI sebagai langkah untuk menjangkau kelompok yang berpendidikan agar dapat lebih memahami dan mengenal pasar modal.

Peran Galeri Investasi BEI sebagai One stop student aktivities pasar modal di dunia akademisi merupakan salah satu sarana pembelajaran yang dapat menjadi sebuah kekuatan untuk mencerdaskan bangsa. Kedepannya melalui laboratorium pasar modal yang menyediakan real time data untuk belajar menganalisa aktivitas perdagangan saham, diharapkan dapat menjadi jembatan menuju penguasaan ilmu pengetahuan beserta prakteknya di Pasar Modal, sehingga perguruan tinggi dapat menghasilkan, masyarakat akademisi yang memahami teori beserta prakteknya.

Dengan adanya kerjasama ini diharapkan dapat saling memberikan manfaat bagi semua pihak sehingga penyebaran informasi pasar modal tepat sasaran serta dapat memberikan manfaat yang optimal bagi mahasiswa, praktisi ekonomi, investor, pengamat pasar modal maupun masyarakat umum di daerah dan sekitarnya baik untuk kepentingan sosialisasi dan pendidikan/edukasi pasar modal maupun untuk kepentingan ekonomis atau alternatif investasi.

\section{Karakteristik Responden Menurut Jenis Kelamin}

Grafik 1. Responden Menurut Jenis Kelamin

\section{Persentase Responden}

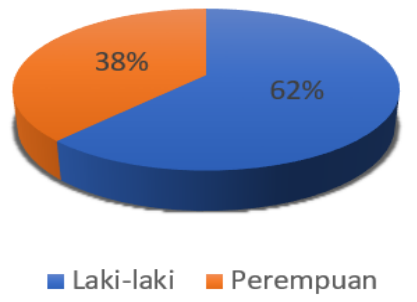

Sumber: Data primer yang diolah, 2018

Dari grafik 1 tampak bahwa sebagian besar responden berjenis kelamin perempuan yaitu sebanyak $(61,90 \% \%)$ sedangkan jenis kelamin laki-laki sebanyak $(38,10 \%)$. Dari sini dapat ditarik kesimpulan bahwa peminat investasi didominasi oleh kaum perempuan daripada laki-laki.

\section{Hasil Olah Data Peneliti Berdasarkan Minat Mahasiswa}

Dari penelitian ini diperoleh hasil bahwa terdapat beberapa faktor yang mempengaruhi minat investasi mahasiswa Program Studi Manajemen Fakultas Ekonomi dan Bisnis UTS melalui Galeri Investasi, yaitu: 


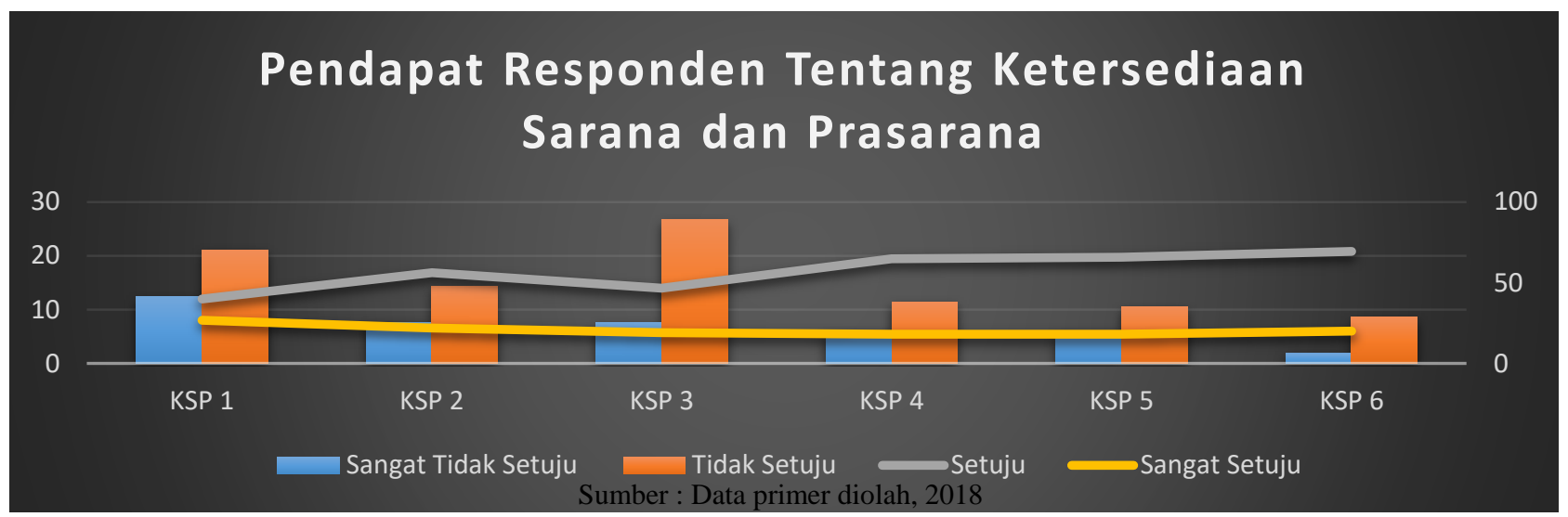

Dari grafik 2 di atas, terlihat bahwa pertanyaan tentang ketersediaan sarana dan prasarana rata-rata responden menjawab setuju dengan pernyataan di dalam kuisioner. Sebanyak 40,0\% responden menjawab setuju terhadap fasilitas ruangan yang nyaman, $56,2 \%$ responden menjawab setuju terhadap fasilitas $\mathrm{WiFi}, 46,7 \%$ responden setuju bahwa

Pendapat Responden Tentang Kualitas SDM

Grafik 3. Pendapat Responden Tentang Kualitas SDM computer yang tersedia di galeri investasi memadai untuk digunakan, $64,8 \%$ responden setuju terhadap mudahnya software transaksi saham, $65,7 \%$ responden setuju terhadap mudahnya proses pembuatan account saham dan $69,5 \%$ responden setuju terhadap ketersediaan buku petunjuk untuk investor saham bagi pemula.

\section{Pendapat Responden Tentang Kualitas SDM}

20,0

20,0
15,0

10,0

5,0

0,0

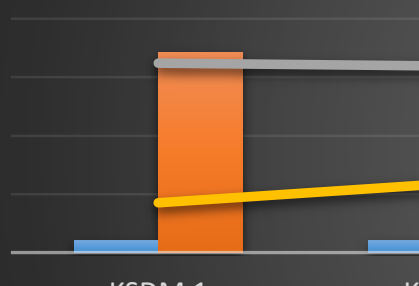

KSDM 1

KSDM 2

KSDM 3

Tidak Setuju

Setuju

Sumber : Data primer diolah, 2018

Dari grafik di atas, terlihat bahwa pertanyaan tentang kualitas SDM rata-rata responden menjawab setuju dengan pernyataan di dalam kuisioner. Sebanyak 64,8\% responden menjawab setuju terhadap seringnya kehadiran petugas di galeri investasi, 63,8\% responden menjawab setuju terhadap keramahan petugas galeri investasi, $66,7 \%$ responden setuju terhadap kooperatifnya petugas galeri terhadap keluhan mahasiswa dalam melakukan transaksi saham, 66,7\% responden setuju terhadap baiknya pemahaman petugas galeri investasi tentang investasi saham dan $62,9 \%$ responden setuju bahwa petugas galeri investasi selalu melakukan sosialisasi tentang pasar modal. 
Grafik 4. Pendapat Responden Tentang Kualitas Sosialisasi dan Pelatihan

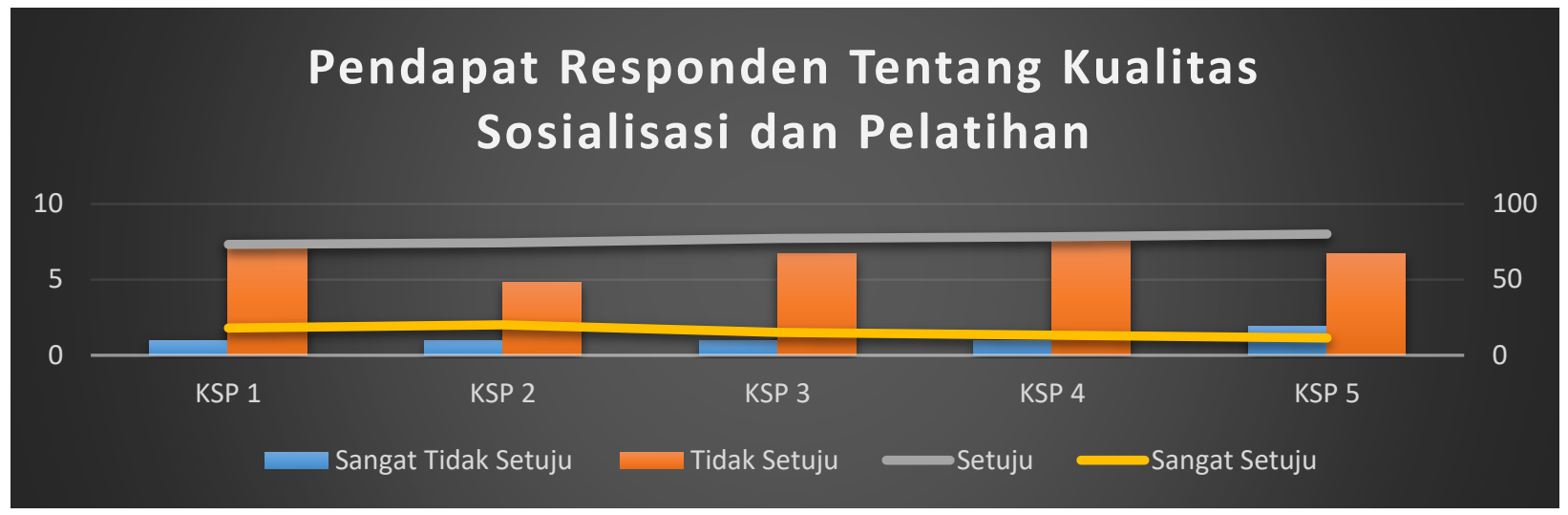

Sumber : Data primer diolah, 2018

Dari grafik di atas, terlihat bahwa pertanyaan tentang kualitas sosialisasi rata-rata responden menjawab setuju dengan pernyataan di dalam kuisioner. Sebanyak $73,3 \%$ responden menjawab setuju bahwa materi pelatihan yang diadakan galeri investasi memberikan pengetahuan tentang produk-produk di pasar modal, 74,3\% responden menjawab setuju bahwa materi yang disampaikan dalam pelatihan pasar modal menarik, jelas, dan mudah dipahami, $77,1 \%$ responden setuju bahwa metode pelatihan yang digunakan dalam menyampaikan materi sangat membantu dalam belajar investasi, 78,1\% responden bahwa pemateri memiliki pengetahuan yang baik dan memadahi sehingga meteri yang disampaikan dapat diterima dengan baik. dan $80,0 \%$ responden setuju bahwa ilmu yang saya dapatkan dalam pelatihan membuat saya tertarik berinvestasi

Pendapat Responden Tentang Harga dan Minimal Investasi

Grafik 5. Pendapat Responden Tentang Harga dan Minimal Investasi

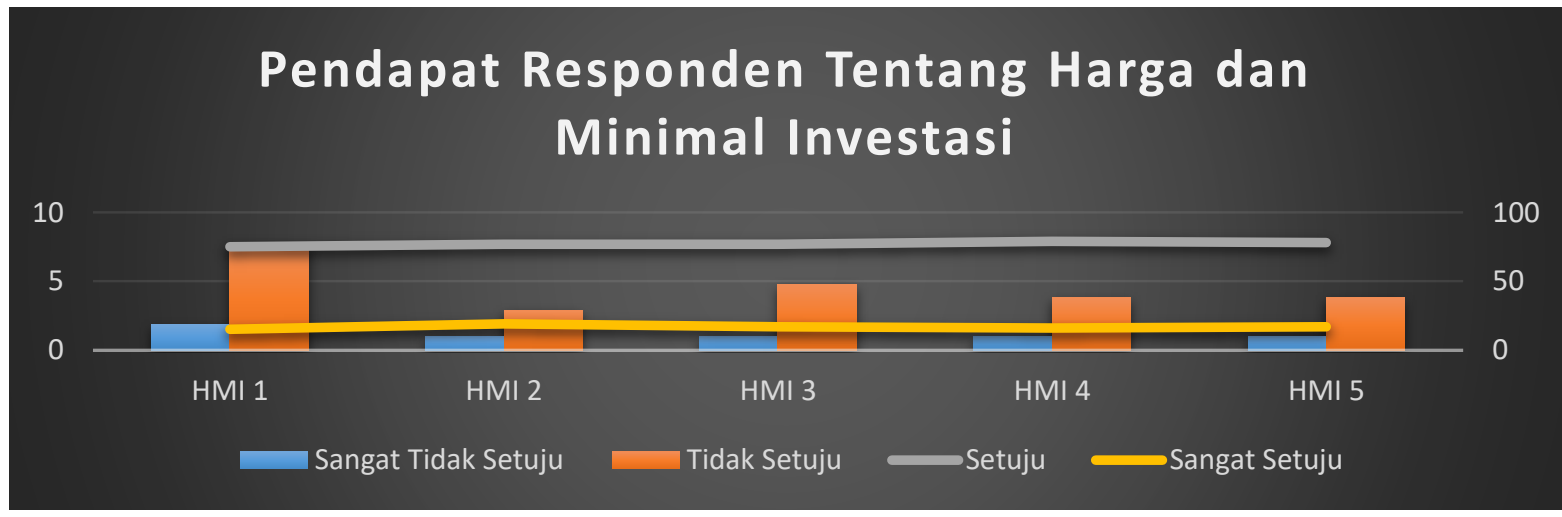

Sumber : Data primer diolah, 2018

Dari grafik di atas, terlihat bahwa pertanyaan tentang harga dan minimal investasi responden menjawab rata-rata setuju dengan pernyataan di dalam kuisioner. Sebanyak 75,2\% responden menjawab setuju bahwa harga produk-produk di pasar modal sangat terjangkau, $77,1 \%$ responden menjawab setuju bahwa BEI memberikan kemudahan dalam investasi, $77,1 \%$ responden setuju bahwa pengurangan jumlah 1 lot menjadi 100 membuat orang tertarik berinvestasi, 79,0\% responden setuju bahwa banyaknya jenis perusahaan dan harga yang ditawarkan di pasar modal memberikan kemudahan untuk memilih produk sesuai bidang yang diinginkan, dan $78,1 \%$ responden setuju produk-produk investasi yang di tawarkan di pasar modal mempunyai variasi harga yang menarik. 


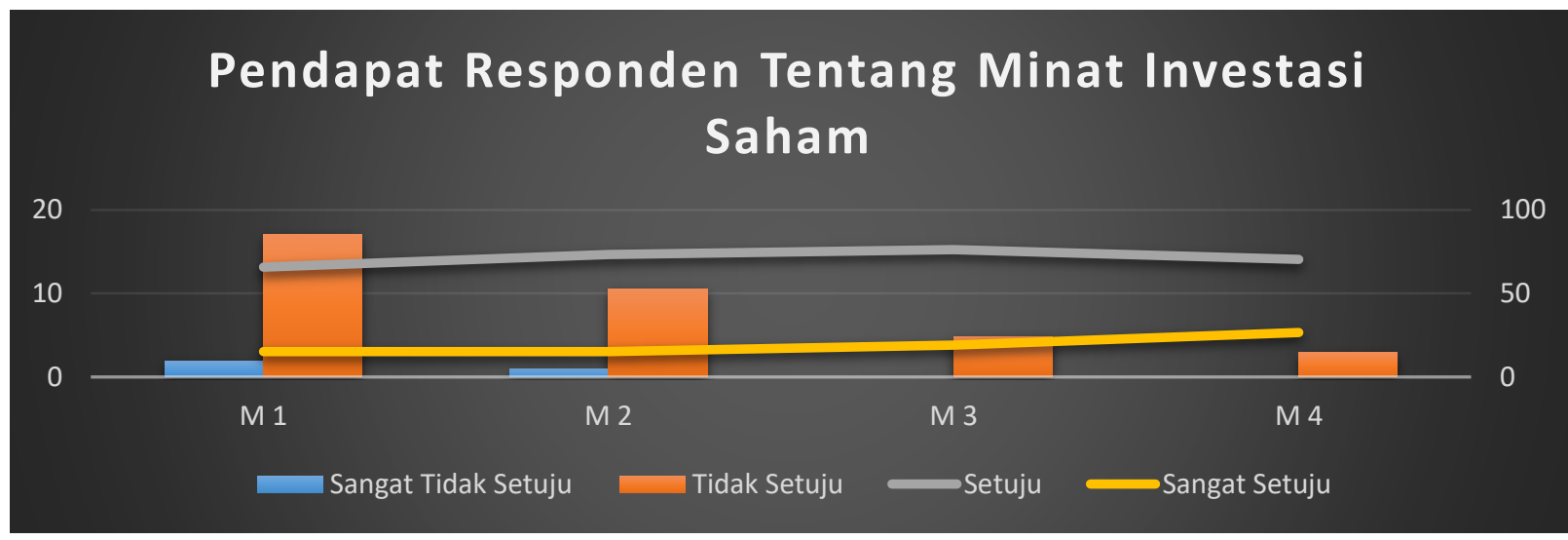

Sumber : Data primer diolah, 2018

Dari tabel di atas, terlihat bahwa pertanyaan tentang minat investasi saham rata-rata responden menjawab setuju dengan pernyataan di dalam kuisioner. Sebanyak $65,7,2 \%$ responden menjawab setuju bahwa responden sering berkunjung ke galeri investasi, $73,3 \%$ responden menjawab setuju bahwa responden selalu mengikuti setiap kegiatan pelatihan/seminar Analisis Data

Pelaksanaan persiapana penelitian dilakukan dengan melakukan uji asumsi klasik untuk memastikan model regresi dapat digunakan. Model regresi linier berganda (multiple regression) dapat disebut sebagai model yang baik jika model tersebut memenuhi Kriteria BLUE (Best Linear Unbiased Estimator). BLUE dapat dicapai bila memenuhi Asumsi Klasik.

Sedikitnya terdapat lima uji asumsi yang harus dilakukan terhadap suatu model regresi tersebut, yaitu:

\section{Uji Normalitas}

Bila rasio kurtosis dan skewness berada di antara -2 hingga +2, maka distribusi data adalah normal (Santoso, 2000: 53). Adapun hasil uji normalitas penelitian ini adalah :

Hasil uji normalitas dengan menggunakan rasio kurtosis diperoleh hasil $0,977 / 0,467=2,00$ dan menggunakan rasio skewness diperoleh hasil $0,356 / 0,236=1,50$. Hasil menggunakan kedua metode tersebut berada diantara -2 hingga +2 , maka dapat disimpulkan data dalam penelitian ini berdistribusi normal.

Tabel 2. Hasil Uji Autokorelasi yang diadakan oleh galeri investasi, 76,2\% responden setuju bahwa responden memiliki keinginan untuk membuat account saham dan berinvestasi di pasar modal, dan $70,5 \%$ responden setuju bahwa dengan berinvestasi saham di pasar modal, saya akan memiliki keuntungan di masa yang akan datang.

\section{Uji Asumsi Klasik}

Tabel 1. Hasil Uji Normalitas

\begin{tabular}{|c|c|c|c|c|}
\hline & \multicolumn{2}{|c|}{ Skewness } & \multicolumn{2}{|c|}{ Kurtosis } \\
\hline & Statistic & $\begin{array}{l}\text { Std. } \\
\text { Error }\end{array}$ & Statistic & $\begin{array}{l}\text { Std. } \\
\text { Error }\end{array}$ \\
\hline \multicolumn{5}{|l|}{ Unstandardized } \\
\hline \multirow{2}{*}{ Valid N (listwise) } & .356 & .236 & .977 & .467 \\
\hline & 105 & 105 & 105 & 105 \\
\hline
\end{tabular}

Sumber : Data primer diolah, 2018

\section{Uji Autokorelasi}

Autokorelasi adalah suatu pengujian yang dilakukan untuk mengetahui korelasi antar sampel yang diurutkan berdasarkan waktu. Untuk mengetahui adanya autokolerasi dilakukan dengan pengujian terhadap nilai uji Durbin Watson (Uji DW). Berikut hasil SPSS pengujian autokorelasi.

\begin{tabular}{|c|c|c|c|c|c|c|c|c|c|c|}
\hline \multirow[b]{2}{*}{ Model } & \multirow[b]{2}{*}{$\mathrm{R}$} & \multirow[b]{2}{*}{ R Square } & \multirow[b]{2}{*}{$\begin{array}{l}\text { Adjusted R } \\
\text { Square }\end{array}$} & \multirow[b]{2}{*}{$\begin{array}{l}\text { Std. Error of } \\
\text { the Estimate }\end{array}$} & \multicolumn{5}{|c|}{ Change Statistics } & \multirow[b]{2}{*}{ Durbin-Watson } \\
\hline & & & & & $\begin{array}{l}\text { R Square } \\
\text { Change }\end{array}$ & F Change & df1 & df2 & $\begin{array}{l}\text { Sig. F } \\
\text { Change }\end{array}$ & \\
\hline 1 & $.342^{\mathrm{a}}$ & .117 & .082 & .41619 & .117 & 3.322 & 4 & 100 & .013 & 1.441 \\
\hline
\end{tabular}

Berdasarkan tabel di atas, dapat diketahui bahwa pada tabel bahwa nilai DW sebesar 1,441, berada diantara -2 hingga 2 . Sehingga dapat disimpulkan tidak terjadi autokorelasi di dalam penelitian ini.

\section{Uji Multikolinieritas}

Gejala multikolinearitas dapat diketahui melalui nilai Variance Inflation Factor (VIF) dan nilai Tolerance. Pengujian ini dilakukan untuk mengetahui korelasi antar 
variabel independen dalam penelitian yang dilakukan. Data dinyatakan tidak memiliki gejala multikolinieritas jika nilai VIF $<10$ dan nilai tolerance $>0,10$ (Sanusi: 2012, 142). Berikut hasil SPSS pengujian multikolinearitas.

Tabel 3. Hasil Uji Multikoleniaritas

\begin{tabular}{lcc}
\hline & \multicolumn{2}{c}{ Collinearity Statistics } \\
\cline { 2 - 3 } Model & Tolerance & VIF \\
\hline (Constant) & .881 & 1.135 \\
Sarana dan Prasarana & .766 & 1.305 \\
Kualitas SDM & .707 & 1.414 \\
Kualitas Sosialisasi & .769 & 1.300 \\
Harga dan Minimal Investasi & &
\end{tabular}

Dari hasil yang didapatkan, korelasi di atas menunjukkan bahwa hubungan antar variabel independen tidak memiliki gejala

multikolinearitas karena semua variabel independen memiliki nilai VIF $<10$ dan nilai tolerance $>0,10$. Maka model regresi layak untuk dipakai.

Uji Heteroskedastisitas

Uji heteroskedastisitas digunakan untuk mengetahui adanya pengaruh-pengaruh variabel yang sulit dipisahkan. Untuk mengetahui ada tidaknya heteroskedastisitas antar variabel dapat dilihat dari hasil pengujian menggunakan metode uji Rank Spearman dengan syarat data dinilai tidak mengalami gejala heteroskedastisitas apabila nilai signifikan >0,05. Adapun hasil pengujian heteroskedastisitas, sebagai berikut:

Tabel 4. Hasil Uji Heteroskedastisitas

\begin{tabular}{|c|c|c|c|c|c|}
\hline \multirow[b]{2}{*}{ Model } & \multicolumn{2}{|c|}{ Unstandardized Coefficients } & \multirow{2}{*}{$\begin{array}{c}\begin{array}{c}\text { Standardized } \\
\text { Coefficients }\end{array} \\
\text { Beta }\end{array}$} & \multirow[b]{2}{*}{$\mathrm{t}$} & \multirow[b]{2}{*}{ Sig. } \\
\hline & B & Std. Error & & & \\
\hline 1 (Constant) & .229 & .256 & & .896 & .373 \\
\hline Sarana dan Prasarana & -.076 & .044 & -.174 & -1.713 & .090 \\
\hline Kualitas SDM & .190 & .064 & .325 & 2.986 & .004 \\
\hline Kualitas Sosialisasi & -.057 & .074 & -.087 & -.770 & .443 \\
\hline Harga dan Minimal Investasi & -.041 & .074 & -.061 & -.560 & .577 \\
\hline
\end{tabular}

Berdasarkan tabel di atas, dapat diketahui bahwa pada tabel bahwa nilai siginifikan variabel memiliki nilai signifikan lebih dari 0,05 ,sehingga dapat disimpulkan tidak terjadi gejala heteroskedastisitas.

\section{Uji Linieritas}

Uji linieritas bertujuan untuk menguji apakah keterkaitan antara dua variabel yang bersifat linier. Perhitungan linieritas digunakan untuk mengetahui prediktor data peubah bebas berhubungan secara linier atau tidak dengan peubah terikat.

Tabel 5. Hasil Uji Linieritas

\begin{tabular}{|c|c|c|c|c|c|c|c|}
\hline & & & $\begin{array}{l}\text { Sum of } \\
\text { Squares }\end{array}$ & Df & Mean Square & $\mathrm{F}$ & Sig. \\
\hline \multirow{5}{*}{$\begin{array}{l}\text { Minat * } \\
\text { Harga dan } \\
\text { Minimal } \\
\text { Investasi }\end{array}$} & Between & (Combined) & 1.497 & 10 & .150 & .776 & .651 \\
\hline & Groups & Linearity & 840 & 1 & 840 & 4.355 & - 040 \\
\hline & & Deviation from Linearity & .657 & 9 & 073 & .378 & .943 \\
\hline & \multicolumn{2}{|c|}{ Within Groups } & 18.126 & 94 & .193 & & \\
\hline & \multicolumn{2}{|l|}{ Total } & 19.623 & 104 & & & \\
\hline
\end{tabular}

Sumber : Data primer diolah, 2018

Berdasarkan tabel di atas, dapat diketahui bahwa pada tabel bahwa nilai siginifikan sebesar 0,943 , lebih besar dari 0,05 sehingga dapat disumpulkan bahwa tidak terdapat hubungan yang linier antara variabel bebas dengan variabel terikat.

\section{Uji Regresi Linier Berganda}

Analisis statistik yang digunakan dalam penelitian ini yaitu regresi linier berganda. Analisis ini digunakan unutk mengetahui besarnya pengaruh variabel - variabel independen yaitu terhadap variabel dependen. Berdasarkan perhitungan diperoleh hasil sebagai berikut 
Tabel 5. Uji Regresi Linier Berganda

\begin{tabular}{|c|c|c|c|c|c|c|}
\hline \multirow[b]{2}{*}{ Mod } & & \multicolumn{2}{|c|}{ Unstandardized Coefficients } & \multirow{2}{*}{$\begin{array}{c}\text { Standardized } \\
\text { Coefficients }\end{array}$} & \multirow[b]{2}{*}{$\mathrm{t}$} & \multirow[b]{2}{*}{ Sig. } \\
\hline & & $\mathrm{B}$ & Std. Error & & & \\
\hline \multirow[t]{5}{*}{1} & (Constant) & 2.033 & .380 & & 5.354 & .000 \\
\hline & Sarana dan Prasarana & .029 & .066 & .044 & .438 & .663 \\
\hline & Kualitas SDM & .251 & .095 & .285 & 2.652 & .009 \\
\hline & Kualitas Sosialisasi & -.107 & .111 & -.108 & -.966 & .336 \\
\hline & $\begin{array}{l}\text { Harga dan Minimal } \\
\text { Investasi }\end{array}$ & .170 & .110 & .166 & 1.553 & .124 \\
\hline
\end{tabular}

Berdasarkan hasil analisis di atas, maka dapat diketahui persamaan regresi yang terbentuk. Adapun persamaan regresi linier yang terbentuk sebagai berikut :

$$
Y=2,033+0,029 X 1+0,251 X 2-0,107 X 3+0,170 X 4+e
$$

Bentuk persamaan di atas dapat diartikan sebagai berikut:

1. Nilai konstanta sebesar 2,033 menunjukkan bahwa ketika nilai variabel independen yaitu variabel sarana dan prasarana, kualitas SDM, kualitas sosialisasi serta harga \& minimal investasi diasumsikan tetap maka nilai minat investasi sebesar 2,033.

2. Nilai koefisien dan prasarana yaitu 0,029 yang apabila nilai Sarana dan Prasarana mengalami kenaikan satu satuan sementara variabel independen lainnya diasumsikan tetap maka nilai minat investasi akan meningkat sebesar 0,029.

3. Nilai koefisien kualitas SDM yaitu sebesar 0,251 hal ini berarti apabila nilai kualitas SDM mengalami kenaikan satu satuan sedangkan variabel independen lain diasumsikan tetap maka nilai variabel minat investasi akan meningkat sebesar 0,251.

4. Nilai koefisien kualitas sosialisasi sebesar $-0,107$ berarti apabila nilai kualitas sosialisasi mengalami peningkatan sebesar satu satuan dan variabel independen lainnya diasumsikan tetap maka nilai minat investasi akan mengalami penurunan sebesar $-0,107$.

5. Nilai koefisien harga dan minimal investasi sebesar 0,170 berarti apabila nilai variabel harga dan minimal investasi mengalami peningkatan sebesar satu satuan dan variabel independen lainnya diasumsikan tetap maka nilai minat investasi akan mengalami peningkatan sebesar 0,170 .

\section{Uji t (Parsial)}

Uji t dilakukan untuk mengetahui sejauh mana variabel independen secara individu (parsial) berpengaruh terhadap variabel dependen serta untuk melihat apakah hipotesis penelitian bisa diterima. Pengaruh variabel independen dikatakan

berpengaruh apabila thitung > ttabel dan nilai signifikan < 0,05 maka disimpulkan variabel independen berpengaruh secara parsial terhadap variabel dependen. Adapun hasil pengujian dari uji t sebagai berikut:

Tabel 6. Uji t Regresi Linier Berganda

\begin{tabular}{llrr}
\hline Model & \multicolumn{1}{c}{$\mathrm{T}$} & \multicolumn{1}{c}{ Sig. } \\
\hline 1 & (Constant) & 5.354 & .000 \\
& Sarana dan Prasarana & .438 & .663 \\
Kualitas SDM & 2.652 & .009 \\
& Kualitas Sosialisasi & -.966 & .336 \\
\multicolumn{2}{c}{ Harga dan Minimal Investasi } & 1.553 & .124 \\
\hline \multicolumn{2}{r}{ Sumber : Data primer diolah, 2018}
\end{tabular}

1. Pengaruh sarana \& prasarana terhadap minat investasi mahasiswa. Variabel sarana \& prasarana memiliki nilai thitung sebesar 0,438 lebih kecil dari nilai t tabel yaitu 1,983 dengan tingkat signifikansi 0,663 >0,05. Hal ini berarti bahwa sarana \& prasarana secara parsial berpengaruh terhadap minat investasi mahasiswa ditolak.

2. Pengaruh kualitas SDM terhadap minat investasi mahasiswa. Variabel kualitas SDM memiliki nilai $\mathrm{t}$ hitung > t tabel yaitu 2,652>1,983 dan nilai signifikan yaitu 0,009 . Yang berarti bahwa H0 ditolak atau hipotesis yang menyatakan kualitas SDM terhadap minat investasi mahasiswa diterima serta nilai signifikan $0,009<0,05$ berarti pengaruhnya signifikan.

3. Pengaruh kualitas sosialisasi terhadap minat investasi mahasiswa. Variabel kualitas sosialisasi mempunyai nilai thitung < ttabel yaitu $-0,966<-1,983$ dan nilai signifikan yaitu $0,336>0,05$. Hal ini berarti bahwa kualitas sosialisasi secara parsial berpengaruh terhadap minat investasi mahasiswa ditolak.

4. Pengaruh harga dan minimal investasi terhadap minat investasi mahasiswa. Variabel harga dan minimal investasi nilai thitung < ttabel yaitu 1,533 < 1,983 dan nilai signifikan yaitu $0,124>0,05$. Hal ini berarti bahwa harga dan minimal investasi secara parsial berpengaruh terhadap minat investasi mahasiswa ditolak.

\section{Uji F (Simultan)}


Tabel 7. Uji F (Simultan) Regresi Linier Berganda

\begin{tabular}{|c|c|c|c|c|c|c|c|c|c|}
\hline \multirow[b]{2}{*}{ Model } & \multirow[b]{2}{*}{$\mathrm{R}$} & \multirow[b]{2}{*}{ R Square } & \multirow[b]{2}{*}{$\begin{array}{l}\text { Adjusted R } \\
\text { Square }\end{array}$} & \multirow[b]{2}{*}{$\begin{array}{l}\text { Std. Error of the } \\
\text { Estimate }\end{array}$} & \multicolumn{5}{|c|}{ Change Statistics } \\
\hline & & & & & $\begin{array}{l}\text { R Square } \\
\text { Change }\end{array}$ & F Change & df1 & df2 & Sig. F Change \\
\hline 1 & $.342^{\mathrm{a}}$ & .117 & .082 & .41619 & .117 & 3.322 & 4 & 100 & .013 \\
\hline \multicolumn{10}{|c|}{ a. Predictors: (Constant), Harga dan Minimal Investasi, Sarana dan Prasarana, Kualitas SDM, Kualitas Sosialisasi } \\
\hline
\end{tabular}

Berdasarkan tabel 4.14 diperoleh hasil perhitungan nilai $\mathrm{F}$ hitung sebesar 3,322 dan Sig. sebesar 0,013 serta diketahui nilai Ftabel yaitu 2,463. Yang berarti bahwa, 3,322 > 2,463 dan disimpulkan bahwa variabel independen meliputi sarana \& prasarana, kualitas SDM, kualitas sosialisasi dan harga \& minimal investasi berpengaruh secara simultan terhadap variabel dependen yakni minat investasi mahasiswa. Selain itu diperoleh nilai Sig. 0,013 $<0,05$ mengindikasikan bahwa pengaruhnya signifikan.

Pada tabel 7 juga menunjukkan nilai R2 sebesar 11,7\% minat investasi mahasiswa dapat di jelaskan oleh empat variabel bebasnya secara bersama-sama yaitu sarana \& prasarana, kualitas SDM, kualitas sosialisasi dan harga \& minimal investasi. Sedangkan sisanya $88,3 \%$ dijelaskan oleh variabel lain di luar model dalam penelitian ini

\section{Penutup}

Minat investasi dipengaruhi oleh beberapa factor antara lain : 1) Ketersediaan Sarana dan Prasarana, 2) Kualitas SDM, 3) Kualitas Sosialisasi dan Pelatihan, 4) Harga dan Minimal Investasi. Dari ke empat faktor di atas, sebagian besar responden setuju dengan pernyataan di dalam kuisioner. Teori return juga mendukung hasil ini. Semakin besar return yang mungkin diperoleh maka semakin besar pula minat investasi. Sebaliknya, semakin kecil return yang mungkin diperoleh maka semakin kecil pula minat investasi.Berdasarkan pada hasil penelitian dan pembahasan yang telah diuraikan sebelumnya maka disimpulkan sebagai berikut : 1) Variabel sarana \& prasarana tidak berpengaruh terhadap minat investasi mahasiswa Program Studi Manajemen Fakultas Ekonomi dan Bisnis FEB UTS. 2) Variabel kualitas SDM berpengaruh terhadap minat investasi mahasiswa Program Studi Manajemen Fakultas Ekonomi dan Bisnis FEB UTS. 3) Variabel kualitas sosialisasi tidak berpengaruh terhadap minat investasi mahasiswa Program Studi Manajemen Fakultas Ekonomi dan Bisnis FEB UTS. 4) Variabel harga dan minimal investasi tidak berpengaruh terhadap minat investasi mahasiswa Program Studi Manajemen Fakultas Ekonomi dan Bisnis FEB UTS.

\section{Daftar Pustaka}

Nurgiyantoro, Burhan dkk. 2012. Statistik Terapan untuk Penelitian Ilmu Sosial. UGM Press Yogyakarta.

Perkasa, Ponttie. P. 2007. “Analisis Pengaruh Rasio-Rasio Keuangan Terhadap Kinerja Bank Umum di Indonesia (Studi Empiris Bank - Bank Umum yang Beroperasi di Indonesia)". Tesis Program Magister Sains Akuntansi Universitas Diponegoro Semarang.

Rusdiana, Nana. 2012. "Analisis Pengaruh CAR, LDR, NIM, NPL, BOPO dan DPK Terhadap Kinerja Keungan Perbankan (Studi Kasus pada Bank Umum yang Terdaftar pada Bursa Efek Indonesia Periode 2008-2011)”. Skripsi Program Ekonomi Manajemen Universitas Diponegoro Semarang.

Sanusi, Anwar. 2012. Metodologi Penelitian Bisnis. Jakarta: Salemba Empat.

Sugiono. 2006. Metodologi Penelitian. Alfabeta: Bandung.

Tandio, Timothius dan Widanaputra, A.A.G.P. 2016. Pengaruh Pelatihan Pasar Modal, Return, Persepsi Risiko, Gender, dan Kemajuan Teknologi pada Minat Investasi Mahasiswa. E-Jurnal Akuntansi Universitas Udayana Vol. 16.3 (ISSN : 2302-8556)

Umar, H. 2008. Manajemen Strategi in Action. PT. Gramedia Pustaka Utama. Jakarta. 